\title{
PENGARUH KOMPETENSI DAN LINGKUNGAN KERJA TERHADAP KINERJA USAHA TANI JERUK PADA BANJAR DINAS TAKSU
}

\author{
N.K. Krismayanti ${ }^{1}$ N.M.D.A. Mayasari ${ }^{2}$ \\ 1,2 Jurusan Manajemen, Universitas Pendidikan Ganesha, Singaraja \\ e-mail: nikadekkrismayanti03@undiksha.ac.id1 dwi.mayasari@undiksha.ac.id²
}

\begin{abstract}
Abstrak
Penelitian ini bertujuan untuk Untuk menguji tentang pengaruh pengaruh kompetensi dan lingkungan kerja terhadap kinerja usaha tani jeruk pada Banjar Dinas Taksu Desa Batur Selatan di Kecamatan Kintamani baik secara parsial maupun simultan. Jenis data yang digunakan dalam penelitian ini adalah data kuantitatif kausal. Objek dalam penelitian ini adalah pengaruh kompetensi dan lingkungan kerja terhadap kinerja. Sedangkan subjek penelitian adalah pelaku usaha tani Banjar Dinas Taksu Desa Batur Selatan Kecamatan Kintamani. Populasi dalam penelitian ini berjumlah 37 responden. Data yang dikumpulkan dalam penelitian ini adalah dengan kuesioner, dan pencatatan dokumen kemudian dianalisis dengan analisis regresi linier berganda pada SPSS For Windows Versi 16.0 Hasil penelitian ini menunjukkan bahwa: kompetensi dan lingkungan kerja berpengaruh secara simultan dan signifikan terhadap kinerja uasa tani jeruk pada Banjar Dinas Taksu Desa Batur Selatan di Kecamatan kintamani.
\end{abstract}

Kata Kunci: Kompetensi, Lingkungan, Kinerja, Usaha Tani

\begin{abstract}
This study aimed at analyzing the effect of the influence of competence and work environment on business performance of citrus farm at Banjar Dinas Taksu Desa Batur Selatan Kecamatan Kintamani either partially or simultaneously. It was causal quantitative data and the object of this study is the influence of competence and work environment on business performance. The subject of study is businessmen at Banjar Dinas Taksu Desa Batur Selatan Kecamatan Kintamani. The population in this study amounted to 37 respondents. The data collected in this study by using questionnaire, and document recording, and then analyzed by multiple liniar regression analysis in SPSS For Windows Versi 16.0. It shows that: competence and work environment simultaneously and significantly influence business performance of citrus farm at Banjar Dinas Taksu Desa Batur Selatan Kecamatan Kintamani.
\end{abstract}

Keywords: competence, environment, performance, citrus farm

\section{Pendahuluan}

Usaha tani merupakan suatu hal yang mempelajari mengenai cara- cara petani dalam mengelola faktor-faktor produksi seperti modal, teknologi, pupuk, tenaga kerja, tanah,dan benih serta cara petani dalam mengelola input secara efisisen, efektif, dan kontinyu agar menghasilkan produksi yang tinggi sehingga dapat meningkatkan pendapatan dari usahanya tersebut. Sektor usaha tani sangat berperan penting bagi perekonomian bangsa Indonesia. Sebagian besar masyarakat pedesaan di Indonesia berpenghasilan dari usaha pertanian untuk dapat memenuhi kebutuhan pangan dan sebagai sumber pendapatan. Soekartawi (2005) mengemukakan bahwa pembangunan usaha tani dapat diarahkan dalam meningkatkan produksi untuk berusaha tani agar bisa memenuhi kebutuhan pangan masyarakat, meningkatkan ekspor, meningkatkan pendapatan dari pertanian, kebutuhan industri dalam negeri, memperluas kesempatan kerja,, serta mendorong pemerataan kesempatan berusaha. Sektor pertanian tergantung pada faktor alam, sehingga factor alam yang berubah sedikit saja akan membuat atau menyebabkan petani gagal panen. Pertanian merupakan hal penting bagi penduduk pedesaan karena pertanian yakni mata pencarian atau lapangan kerja utama bagi penduduk pedesaan, sehingga dalam pembangunan-pembangunan di pedesaan perhatian 
pertamanya ditunjukan dalam pembangunan pertanian yang menjadi sektor aktivitas ekonomi. Dalam pencapaian kinerja diharapkan adanya kemampuan kompetensi untuk meningkatkan kinerja.

Menurut Moehariono (2012) kinerja adalah suatu hal mengenai gambaran tentang tingkat pencapaian seseorang dalam melaksanakan suatu kegiatan untuk menghujudkan visi organisasi, misi, tujuan,dan sasaran yang tertuang pada strategik planning di suatu organisasi. Pengukuran kinerja merupaka proses untuk menilai kemajuan dari pekerjaan tersebut terhadap sasaran dan tujuan yang sudah ditentukan sebelumnya, termasuk informasi atas efisiensi penggunaan sumber daya dalam menghasilkan suatu barang atau jasa, hasil kegiatan dibandingkan dengan maksud yang diinginkan, kualitas barang dan jasa serta efektivitas dalam mencapai tujuan. Riyanti (2003:23) mengemukakan bahwa di setiap usaha pasti selalu ingin mencapai suatu sasaran yang sudah ditetapkan atau ingin mencapai suatu keberhasilan dari usahanya. Pihak lain Rivai dan Ahmad (2005:35) menegaskan bahwa kinerja merupakan suatu hasil pekerjaan yang dapat dicapai oleh seseorang maupun sekelompok orang dalam penacapain tujuan secara legal, tidak dapat melanggar hukum atau tidak bertentangan dengan moral dan etika. Berdasarkan wawancara dengan 10 petani jeruk di Banjar Dinas Taksu, diketahui bahwa kinerja petani, dalam mengelola usaha taninya belum maksimal hal ini dibuktikan dengan belum tercapainya (1) kualitas yaitu suatu tingkat mengenai seberapa baik seorang petani mengerjakan beberapa hal yang seharusnya dikerjakan oleh petani. (2) kuantitas adalah suatu tingkat mengenai berapa lama petani bekerja dalam organisasi yang dapat dilihat dari kecepatan bekerja petani (3) ketepatan waktu yaitu suatu aktivitas dari petani untuk menyelesaikan pekerjaan yang diinginkan. (4) efektivitas yaitu Suatu keadaan yang menenjukkan tingkat dari keberhasilan atau pencapaian dari suatu tujuan yang bisa diukur dengan kualitas, kuantitas, dan dengan waktu yang sudah direncanakan sebelumnya.(5) Kemandirian, yaitu suatu tingkat dimana seorang petanii melakukan pekerjaannya tanpa bantuan dari orang lain atau petani lain untuk mernghindari hasill yang merugikan.

Permasalahan yang di hadapi petani di Banjar Dinas Taksu dalam efektivitas, kualitas, ketepatan waktu, kuantitas dan kemandirian kerjanya yaitu karena rendahnya tingkat pendidikan yang dimiliki oleh petani yang menyebabkan petani Banjar Dinas Taksu tidak mampu untuk berkomunikasi dengan baik, dengan penjual jeruk lainya dan lemahnya teknologi yang dimiliki petani mengakibatkan petani menjual hasil panenya ke sesama petani di Banjar Dinas Taksu. Belum tercapainya target panen dalam usahanya disebabkan karena kurangnya kemampuam petani dalam merawat hasil usaha taninya sehingga banyak buah jeruk yang terserang penyakit yang menyebabkan petani gagal panen. Ketepatan waktu dalam bekerja juga sangat penting dimana jika petani tidak bisa menyelesaikan perkerjaannya sesui dengan waktu yang telah ditentukan maka kinerja yang dihasilkan oleh petani belum maksimal. Selain itu permasalahan petani berdasarkan kemandiriannya adalah kurangnya kemampuan inisiatif yang dimiliki petani sehingga petani hanya menunggu intruksi untuk bekerja. Purnami (2014) menyatakan bahwa dalam peencapaian kinerja yang baik sangat diperlukan adanya sumber daya manusia yang mempunyai tingkat kemampuan, kimpetensi dan motivasi dan sehingga dapat meningkatkan kinerja.

Kompetensi dapat diartikan sebagai kombinasi antara, keterampilan, pengetahuan dan kepribadian yang bisa meningkatkan kinerja sehingga dapat memberikan kontribusi untuk kesuksesan dari organisasinya. Pengertian kompetensi menurut Robbin (2007:38), kompetensi adalah suatu kemampuan yang dimiliki oleh seseorang atau kapasitas seseorang bagaimana seseorang tersebut dapat mengerjakan berbagai tugas yang dibebankan atau dituntut dari pekerjaan tersebut dimana kemampuan dapat ditentukan oleh dua faktor yaitu kemampuan fisik dan intelektual. Moehariono (2012) menambahkan bahwa jika seseorang memiliki kompetensi secara baik atau tinggi bila diintegritaskan menggunakan kompetensi jabatanya maka seseorang tadi tersebut kemungkinan besar akan bisa membentuk kinerja secara optimal. Maka kemungkinan besar bahwa ada pengaruh dari kompetensi. secara parsial terhadap kinerja hal 
ini sejalan dengan penelitian yang dilakukan oleh Pinem (2019). Dalam menjalankan pekerjaannya setiap petani tentunya harus memiliki kompetensi yang dapat diandalkan untuk pekerjanya. Kompetensi akan menjadi bekal dan modal bagi petani jeruk di Banjar Dinas Taksu untuk bekerja secara profesional.

Kompetensi harus diasah dan ditingkatkan bagi petani sehingga memperoleh kinerja yang bagus. Berdasarkan informasi dari 10 petani jeruk di Banjar Dinas Taksu bahwa permasalahan yang terjadi mengenai kompetensi adalah kemampuan petani untuk memasarkan hasil usahanya masih belum maksimal karena kebanyakan petani di Banjar Dinas Taksu menjual hasil taninya kepada sesama petani Banjar Dinas Taksu sehingga hasil panen terjual dengan harga yang cukup rendah, disamping itu banyaknya pesaing-pesaing baru yang menanam berbagai jenis jeruk menyebabkan hasil panen di Banjar Dinas Taksu Desa Batur Selatan dibeli dengan harga yang cukup rendah karena kemampuan petani dalam mengelola hasil usaha taninya masih belum maksimal. Dari 10 petani jeruk di Banjar Dinas Taksu menyatakan bahwa rendahnya pendidikan petani yaitu tamat SD/ sederajat bahkan ada yang tidak tamat SD pada petani di Banjar Dinas Taksu yang mengakibatkan kinerja petani menjadi rendah salah satunya adalah kurangnya pengetahuan yang dimiliki oleh petani. Rendahnya pendidikan petani di Banjar Dinas Taksu membuat kebanyakan petani Banjar Dinas Taksu masih menitikberatkan tradisi masa lalu untuk melakukan praktek pertanian.Tingkat pendidikan dapat menunjang pencapaian kinerja petani karena dengan menempuh tingkat pendidikan yang tinggi akan menyebabkan seseorang mempunyai keahlian tertentu. Menurut Bagia (2015) menyatakan bahwa semakin tinggi kompetensi yang dimiliki oleh seseorang atau sesuai dengan tuntutan pekerjaannya maka kinerja dari pegawainya semakin tinggi atau meningkat. Dalam pembangunan-pembangunan pertanian, mempunyai arti yang sangat penting, karena bisa mempertinggi kemampuan untuk mengatasi teknologi baru di bidang pertanian, maka penerapan dari teknologi tersebut akan menjadi lebih sempurna, yang pada akhirnya akan memberikan hasil lebih memuaskan baik secara kualitas maupun kuantitas.

Kinerja seseorang tidak ditentukan dari pengetahuan atau kemampuanya, tidak juga dari iming-iming gaji yang besar melainkan kinerja ditentukan oleh motivasi dalam bekerja. Motivasi dalam pekerjaan seseorang dapat di pengaruhi dari dalam maupun dari luar diri yang bersangkutan. Motivasi dari luar salah satunya dapat ditentukan oleh kondisi dimana seseorang tersebut bekerja yaitu dengan melihat bagimana hubungan kerja seseorang dengan rekan kerjanya. Untuk dapat memiliki hubungan yang baik dengan rekan kerja kunci utamnya yaitu komunikasi. Komunikasi dari masing-masing petani dalam tim kerja sangat menentukan apakah petani dapat menunjukan performa kerja yang baik atau tidak. (Antoni 2006) mengemukakan bahwa pemberian dorongan adalah salah satu dari bentuk motivasi, dimana pemberian motivasi sangat penting dilakukan oleh seseorang untuk meningkatkan gairah kerja petani sehingga dapat mencapai hasil yang maksimal. Selain itu lingkungan kerja juga berpengaruh positif terhadap kinerja yang nantinya mampu menjamin kinerja pertani menjadi lebih baik dan pada akhirnya memungkinkan usaha petani untuk memperoleh sikap dan prilaku yang positif. Hal ini dipertegas oleh Musriha (2011) yang menyatakan bahwa lingkungan kerja memiliki dampak positif terhadap kinerja.

Lingkungan kerja adalah suatu hal suatau hal yang ada di lingkungan tempat bekerja dimana bisa mempengaruhi pekerjaanya dalam menjalankan tugas yang dibebankan oleh atasannya. Schultz dan Schultz (2006) lingkungan kerja merupakan kondisi yang berkaitan dengan tempat dimana seseorang tersebut melakukan pekerjaanya dengan prilaku atau sikap yang dapat berhubungan dengan perubahan psikologis karena suatu hal yang dapat diaalami dalam pekerjaan serta suatu keadaan tertentu yang harus dapat perhatian oleh organisasi yang mencakup dari kebosanan dalam bekerja pekerjaan yang monoton, dan kelelahan. Sedangkan Sedarmayati (2009) memberikan pendapat bahwa lingkungan kerja merupakan sebagai keseluruhan alat- alat perkakas yang digunakan dalam bekerja atau bahan yang dihadapi untuk bekerja di lingkungan sekitar dimana seseorang tersebut bekerja serta metode kerja yang 
digunakan seperti apa baik sebagai perseorangan maupun sebagai kelompok. Hal ini juga dapat didukung oleh ( Suryadi dan Rosyidi, 2013) yang mengemukakan pendapatnya yaitu bahwa lingkungan kerja berpengaruh secara parsial terhadap kinerja pengusaha.

Lingkungan kerja menjadi salah satu hal yang dapat memengaruhi produktivitas dan semangat kerja petani. Tanpa lingkungan kerja yang baik atau kondusif, petani akan mudah bosan dan tidak betah untuk bekerja. Secara umum ada dua jenis lingkungan kerja yaitu sebagai berikut lingkungan kerja non fisik dan fisik. Lingkungan fisik merupakan suatu keadaan yang berbentuk secara fisik yang ada di sekitar tempat bekerja. sedangkan lingkungan kerja non fisik adalah semua hubungan yang terdapat dalam urusan kerja. Jenis lingkungan kerja fisik dan non fisik yaitu suatu hal yang sangat berpengaruh terhadap kinerja dan produktivitas petani, ketika petani-petani berada di dalam lingkungan yang sangat mendukung untuk menyelesaikan pekerjaanya, maka akan lebih efektif dan efisien dalam mengasilkan pekerjaan yang maksimal. Sebaliknya jika lingkungan kerja petani tidak mendukung petani untuk menyelesaikan pekerjaanya dengan maksimal maka akan sulit memperoleh sistem kerja yang efektif dan efisien. Salah satu hal yang mempengaruhi petani dalam mengerjakan tugasnya secara maksimal yaitu cuaca dimana pada saat musim panas dan musim hujan para petani tidak bisa bekerja secara maksimal.

Kecamatan Kintamani merupakan pengembang tanaman jeruk potensial di Bali, hal ini yang disebabkan oleh keadaan lingkungannya seperti (suhu, iklim, tanah, ketinggian tempat). Hasil dari pra survei diketahui bahwa budidaya tanaman jeruk di Banjar Dinas Taksu, Desa Batur Selatan, Kecamatan Kintamani sudah banyak dikembangkan oleh masyarakat baik sebagai penghasilan pokok maupun penghasilan sampingan, usaha tani tanaman jeruk tidak mudah karena banyak yang terserang penyakit yang menyebabkan gagal panen, dan biaya yang digunakan dalam mengelola usaha ini cukup tinggi seperti (biaya pengolahan lahan, biaya tenaga kerja, biaya angkut). Adapun beberapa masyarakat Banjar Dinas Taksu menjual buah jeruk di pinggir jalan, karena beberapa petani tidak memiliki alat transportasi untuk memasarkannya.

Petani jeruk di Banjar Dinas Taksu Desa Batur Selatan dapat dikatakan berhasil dalam menjalani suatu usahanya apabila para petani mampu untuk mengelola hasil usahanya secara maksimal dan mampu meningkatkan target produksinya pada saat petani panen raya yang dapat terjadi dua kali dalam setahun. Seiring dengan peningkatan dari produksi usaha pertanianya akan membuat peningkatan laba dari hasil usaha taninya. Sebagai tanaman tahunan yang hasilnya hanya bisa dinikmati oleh masyarakat secara ekonomis yaitu setelah jeruk berumur sakitar 5 tahun, pengembangan jeruk sebelumnya harus direncanakan secara tepat agar tercapai produktivitas dan keutungan yang diinginkan oleh masyarakat.

Perencanaan dalam usaha tani jeruk dilakukan dengan menentukan lingkungan kebun yang sesuai sama kebutuhan dalam bercocok tanam adalah kunci dalam meraih kesuksesan. Begitu juga sebaliknya, jika terjadi kesalahan dalam menentukan lingkungan kebun akan berdampak buruk dan pengaruh negatif akan terlihat saat tanaman memasuki usia produktif yang sudah menghabiskan banyak biaya dalam aspek pemeliharaan. Selain itu Faktor dari lingkungan juga akan menandakan dalam usaha tani jeruk seperti suhu, curah hujan, ketinggian tempat, kesuburan tanah, kelembaban udara, dan intensitas cahaya matahari. Berdasarkan permasalahan diatas maka dilakukan mengenai "Pengaruh Kompetensai dan Lingkungan Kerja Terhadap Kinerja Usaha Tani Jeruk pada Banjar Dinas Taksu”. Tujuan penelitian ini yaitu untuk menguji tentang bagaimana pengaruh kompetensi dan lingkungan kerja terhadap kinerja usaha tani jeruk pada Banjar Dinas Taksu Desa Batur Selatan Di Kecamatan Kintamani baik secara simultan maupun parsial.

\section{Metode}

Metode yang dipakai pada penelitian ini merupakan pencatatan dokumen dan kuesioner. Pencatatan dokumen adalah teknik dalam pengumpulan data dengan menggunakan cara 
mencatat hal-hal yang berkaitan dengan masalah dalam penelitian. Kuesioner adalah teknik dalam pengumpulan data yang dilakukan dengan menggunakan pernyataan tertulis atau seprangkat pertanyaan pada responden buat dijawab sesuai dengan kenyataan.

Sumber data yang dipakai dalam penelitian yang berjudul pengaruh kompetensi dan lingkungan kerja terhadap kinerja usaha tani jeruk pada Banjar Dinas Taksu adalah sumber data yang berasal dari data sekunder dan dari data primer. Data primer adalah suatu data yang dapat diperoleh dari individu, sumber pertama, maupun perseorangan yaitu seperti dari hasil pengisian kuesioner yang dilakukan oleh peneliti). Data sekunder, adalah suatu data primer yang diolah lebih lanjut yang dapat disajikan dari pengumpulan data primer yang berupa bentuk gambar maupun tabel

Metode analisis yg dipakai pada penelitian ini merupakan analisis analisis regresi linieri berganda. Analisis regresi liner berganda dilakukan pada penelitian ini menggunakan dengan memasukan satu variabel dependent dan dua variabel independent analisis regresi berganda ini diolah dengan memakai SPSS For Windows versi 16.0. Secara umum formulasi regresi linier berganda bisa ditulis seperti berikut:

$$
Y=\alpha+\beta_{1} X_{1}+\beta_{2} X_{2}+\varepsilon
$$

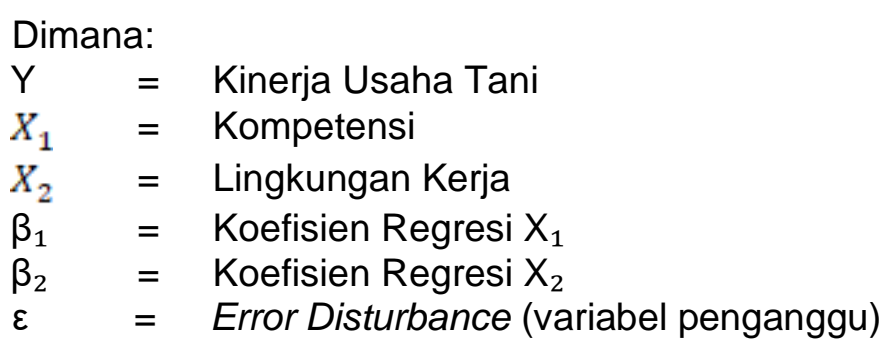

\section{Hasil dan Pembahasan}

Hasil penelitian menerangkan bahwa terdapat pengaruh kompetensi dan lingkungan kerja terhadap kinerja usaha tani jeruk Banjar Dinas Taksu Desa Batur Selatan pada Kecamatan Kintamani.

\begin{tabular}{|c|c|c|c|c|c|c|}
\hline & \multirow[t]{2}{*}{ Model } & \multicolumn{2}{|c|}{$\begin{array}{c}\text { Unstandardized } \\
\text { Coefficients }\end{array}$} & \multirow{2}{*}{$\begin{array}{c}\text { Standardized } \\
\text { Coefficients } \\
\text { Beta }\end{array}$} & \multirow[t]{2}{*}{$\mathrm{t}$} & \multirow[t]{2}{*}{ Sig. } \\
\hline & & $\mathrm{B}$ & Std. Error & & & \\
\hline \multirow{3}{*}{1} & (Constant) & 2,621 & 2,281 & & 1,149 & 0,259 \\
\hline & Total_X $\mathrm{X}_{1}$ & 0,387 & 0,143 & 0,372 & 2,707 & 0,011 \\
\hline & Total_X $\mathrm{X}_{2}$ & 0,668 & 0,175 & 0,524 & 3,817 & 0,001 \\
\hline
\end{tabular}

Berdasarkan tabel 1 diatas, dapat dilihat nilai t sebesar 2,707 untuk varibel kompetensi dengan nilai $p$-value sebesar $0,011<$ alpha $=0,05$. Hal ini menyatakan bahwa hipotesis menolak Ho yang artinya bahwa ada pengaruh dari kompetensi $\left(\mathrm{X}_{1}\right)$ terhadap kinerja $(\mathrm{Y})$. Peningkatan kompetensi terhadap petani jeruk Banjar Dinas Taksu dapat dilakukan melalui pemberian pelatihan mengenai hal-hal yang berkaitan dengan pertanian jeruk, marketing untuk menjual hasil panen jeruk dengan harga yang dapat mensejahterakan petani serta administrasi keuangan untuk mengatur keuangan petani guna keberlangsungan usaha Tani. Kegiatan pelatihan ini dapat diajukan oleh perkumpuln petani jeruk Banjar Dinas Taksu kepada instansi pemerintah Kecamatan Kintamani mengenai perihal pelatihan keterampilan. Cara lain yang dapat dilakukan adalah dengan bekerjasama dengan pihak-pihak universitas dalam kegiatan pengabdian kepada masyarakat. 
Selain itu dapat dilihat juga nilai t sebesar 3,817 untuk varibel lingkungan kerja dengan nilai $p$-value sebesar $0,001<$ <alpha $=0,05$. Hal ini menyatakan bahwa hipotesis menolak Ho yang artinya bahwa ada pengaruh dari lingkungan kerja $\left(\mathrm{X}_{2}\right)$ terhadap kinerja $(\mathrm{Y})$. Hal ini juga dapat dilihat dari salah satu hal yang mempengaruhi petani dalam mengerjakan tugasnya secara maksimal yaitu cuaca dimana pada saat musim panas dan musim hujan para petani tidak bisa bekerja secara maksimal. Tersedinya fasilitas kerja yang lengkap dan hubungan dengan rekan kerja juga mempengaruhi petani dalam bekerja jika petani tidak memiliki fasilitas kerja dan hubungan dengan rekan kerjanya tidak baik maka petani tidak bisa menyelesaikan pekerjaan dengan tepat waktu atau sesuai dengan target yang sudah ditetapkan. Adanya lingkungan kerja yang sangat mendukung akan membuat para kinerja petani akan bekerja lebih baik dari pada sebelumnya. Petani yang mempunyai pekerjaan yang baik akan memberikan dampak pada positif untuk peningkatan kinerja dari petani. Tempat kerja yang bersih, nyaman, hubungan sosial dengan sesama rekan kerja baik dan kondusif, serta tersedianya fasilitas kerja yang lengkap dan kondisi kerja yang mendukung akan membawa masyarakat petani untuk bekerja dengan lebih baik dan menumbuhkan rasa semangat kerja yang tinggi serta dapat menghasilkan kinerja yang tinggi pula. Sehingga tidak terjadinya suasana kerja yang tidak nyaman, penumpukan tugas yang sangat mengganggu rekan kerja lain serta tersedianya fasilitas kerja yang lebih lengkap membuat para petani lebih mudah dalam menyelesaikan pekerjaannya serta lebih efektif dalam menyelesaikan pekerjaan guna untuk mendukung kegiatan petani. Lingkungan kerja yang kurang mendukung dapat membawa dampak negatif bagi petani dan secara otomatis dapat menurunkan tingkat kinerja petani, karena petani dalam melaksanakan tugasnya akan mengalami ganguan-gangguan, sehingga menyebabkan petani kurang semangat dan kurang mencurahkan tenaga dan pikirannya terhadap tugas yang telah dibebankan kepada petani. Ketika petani Banjar Dinas Taksu bekerja di lingkungan kerja yang mendukung dan kondusif serta hubungan sesama rekan kerja pun baik, maka kinerja petani akan cenderung bekerja lebih baik.

\begin{tabular}{ccccccc}
\multicolumn{8}{c}{ Tabel 2. Hasil Pengujian F } \\
\hline \multirow{2}{*}{ Model } & Sum of & df & Mean & F & Sig. \\
& Squares & & Square & & \\
\hline \multirow{2}{*}{1} & Regression & 199,533 & 2 & 99,767 & 38,745 & $0,000^{\mathrm{a}}$ \\
& Residual & 87,548 & 34 & 2,575 & & \\
& Total & 287,081 & 36 & & & \\
\hline
\end{tabular}

Berdasarkan tabel dua diatas, bisa dianalisis nilai $F_{\text {hitung }}$ yaitu 38,745,dengan menggunakan probabilitas 0,000 . Karena probabilitas $0,000<$ alpha sebesar 0,05. Hasil penelitian menyatakan bahwa hipotesis menolak Ho yang artinya bahwa ada pengaruh simultan dari kompetensi $\left(\mathrm{X}_{1}\right)$ dan lingkungan kerja $\left(\mathrm{X}_{2}\right)$ terhadap kinerja $(\mathrm{Y})$. Hasil penelitian ini terlihat bahwa kompetensi dan lingkungan kerja menunjukan pengaruh bersama - sama secara signifikan terhadap kinerja usaha tani Banjar Dinas Taksu Desa Batur Selatan pada Kecamatan Kintamani.

Kompetensi dan lingkungan kerja dalam sebuah usaha sangat diperlukan, dimana semakin luas wawasan dan keterampilan seseorang maka semakin berpengaruh terhadap usahanya. Kebersihan lingkungan dapat mempengaruhi seseorang secara tidak langsung dalam bekerja, karena jika lingkungan kerja mempunyai fasilitas kerja lengkap, hubungan sesama rekan kerjanya baik dan suasana kerjanya mendukung maka petani akan merasa nyaman untuk melakukan pekerjaannya. Kajian empirik yang mendukung penelitian ini adalah hasil penelitian yang dilakukan oleh Efendi dkk (2017) membuktikan bahwa kompetensi dan lingkungan kerja akan memberikan berpengaruh secara simultan terhadap kinerja. Hal ini juga sesuai dari penelitian Rahmisyari (2017) yang membuktikan bahwa dari kedua variabel bebas 
kompetensi $\left(\mathrm{X}_{1}\right)$ dan lingkungan kerja $\left(\mathrm{X}_{2}\right)$ memberikan pengaruh yang signifikan secara bersama- sama terhadap kinerja $(Y)$. Rendahnya kinerja usaha tani jeruk pada Banjar Dinas Taksu Desa Batur Selatan di Kecamatan Kintamani dibuktikan dengan rendahnya pendidikan petani di Banjar Dinas Taksu, belum tercapainya target panen, ketepatan waktu dalam bekerja dan kurangnya kemampuan inisiatif dalam bekerja serta lingkungan kerja yang dirasa kurang nyaman oleh pekerja.

Menurut Nitisemito (1992) menegaskan kompetensi dan lingkungan kerja memberikan pengaruh yang simultan secara bersama-sama terhadap kinerja. Adanya pengaruh dari kompetensi dan lingkungan kerja secara positif dan signifikan terhadap kinerja petani jeruk Banjar Dinas Taksu mengindikasikan bahwa kedua hal ini hendaknya diperhatikan dengan seksama oleh para petani jeruk. Membangun kekuatan dari kedua variabel ini akan memberikan dampak secara bersama-sama terhadap peningkatan kinerja petani jeruk dibandingkan hanya mengembangkan satu variabel saja.

Tabel 3. Hasil Analisis Regresi Linear Berganda

\begin{tabular}{|c|c|c|c|c|c|}
\hline Parameter & Nilai & 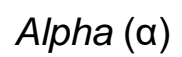 & $P$-Value & Keputusan & Kesimpulan \\
\hline $\begin{array}{c}\mathrm{F}_{\text {hitung }}> \\
\mathrm{F}_{\text {tabel }}\end{array}$ & $\begin{array}{c}38,745> \\
3,27\end{array}$ & 0,05 & 0,000 & Menolak Ho & $\begin{array}{l}\text { Yang artinya ada pengaruh } \\
\text { secara simultan dari variabel } \\
\text { kompetensi }\left(X_{1}\right) \text { dan variabel } \\
\text { lingkungan kerja }\left(X_{2}\right) \text { terhadap } \\
\text { kinerja usaha tani jeruk }\end{array}$ \\
\hline $\mathrm{R}^{2}$ & 0,695 & - & - & - & $\begin{array}{l}\text { Yang menunjukkan bahwa ada } \\
\text { pengaruh secara simultan dari } \\
\text { variabel kompetensi }\left(X_{1}\right) \text { dan } \\
\text { variabel lingkungan kerja }\left(X_{2}\right) \\
\text { yaitu sebesar } 69,5 \%\end{array}$ \\
\hline$\varepsilon$ & 0,305 & - & - & - & $\begin{array}{l}\text { Yang Menunjukkan bahwa ada } \\
\text { pengaruh dari faktor lain } \\
\text { terhadap kinerja usaha tani } \\
\text { jeruk sebesar } 30,5 \% \text {. }\end{array}$ \\
\hline $\mathrm{Pyx}_{1}$ & 0,751 & 0,05 & 0,000 & Menolak Ho & $\begin{array}{l}\text { Yang artinya ada pengarun } \\
\text { parsial dari kompetensi } \\
\text { terhadap kinerja usaha tani } \\
\text { jeruk. }\end{array}$ \\
\hline $\mathrm{Pyx}_{2}$ & 0,793 & 0,05 & 0,000 & Menolak Ho & $\begin{array}{l}\text { Yang artinya Ada hubungan } \\
\text { secara parsial dari pengaruh } \\
\text { lingkungan kerja terhadap } \\
\text { kinerja usaha tani jeruk. }\end{array}$ \\
\hline$\alpha$ & 2.621 & 0,05 & 0,000 & Menolak Ho & $\begin{array}{l}\text { Yang artinya Dapat } \\
\text { mempengaruhi tingkat kinerja } \\
\text { usaha tani jeruk. }\end{array}$ \\
\hline$\beta_{1}$ & 0,387 & 0,05 & 0,000 & Menolak Ho & $\begin{array}{l}\text { Yang artinya ada pengaruh } \\
\text { dari variabel kompetensi }\left(\mathrm{X}_{1}\right) \\
\text { terhadap kinerja }(\mathrm{Y}) \text { usaha tani } \\
\text { jeruk yaitu sebesar } 38,7 \% \text {. }\end{array}$ \\
\hline$\beta_{2}$ & 0,668 & 0,05 & 0,000 & Menolak Ho & $\begin{array}{l}\text { Yang artinya ada pengaruh } \\
\text { dari variabel lingkungan kerja } \\
\text { terhadap kinerja usaha tani } \\
\text { jeruk yaitu sebesar } 66,8 \%\end{array}$ \\
\hline
\end{tabular}


Berdasarkan hasil analisis data pada variabel kompetensi dan lingkungan kerja terhadap kinerja usaha tani pada Banjar Dinas Taksu Desa Batur Selatan di Kecamatan Kintamani dengan menggunakan metode analisis regresi linier berganda yang dibantu oleh program (SPSS) 16. For windows, maka dapat diperoleh hasil analisis dengan persamaan sebagai berikut.

$$
Y=2,621+0,387 X_{1}+0,668 X_{2}+0,305
$$

Dimana:

$\mathrm{Y}=$ Variabel dependent (Kinerja)

$\alpha=$ Konstanta

$\beta_{1} \beta_{2}=$ Koefisien regresi dari tiap-tiap variabel independen

$\mathrm{X}_{1}=$ Kompentensi

$\mathrm{X}_{2}=$ Lingkungan Kerja

Interpretasi dari hasil analisis regresi linier berganda yaitu sebagai berikut.

Nilai Konstanta sebesar 2,621 artinya bahwa apabila kompetensi dan lingkungan kerja nilainya sama dengan nol, maka kinerja nilainya sebesar 2,621. Nilai koefisien kompetensi $\left(\beta X_{1}\right)$ sebesar 0,387 berpengaruh secara parsial terhadap kinerja. Hal ini dapat mengandung arti bahwa setiap kenaikan kompetensi satu satuan maka variabel kinerja mengalami kenaikan sebesar 2,621 + 0,387 sehingga menjadi 3,008 dengan asumsi bahwa variabel bebas yang lainnya tetap. Nilai koefisien lingkungan kerja $\left(\beta \mathrm{X}_{2}\right)$ sebesar 0,668 Berpengaruh secara parsial terhadap variabel kinerja. Hal ini mengandung arti bahwa setiap kenaikan lingkungan kerja satu satuan maka kinerja mengalami kenaikan sebesar 2,621 + 0,668 sehingga menjadi 3,289 dengan asumsi bahwa variabel bebas yang lain tetap.

\section{Simpulan dan Saran}

Dapat disimpulkan bahwa kompetensi memberikan pengaruh terhadap kinerja usaha tanii jeruk pada Banjar Dinas Taksu Desa Batur Selatan di Kecamatan Kintamani secara positif dan signifikan yang ditunjukkan dengan hasil yaitu t-hitung 2,707 dan nilai signifikansi 0,011. yang Artinya, jika kompetensi yang dimiliki oleh petani Banjar Dinas Taksu tinggi dan sesuai dengan standar pekerjaan maka kinerja usaha tani semakin meningkat.

Lingkungan kerja memberikan berpengaruh terhadap kinerja usaha tani pada Banjar Dinas Taksu Desa Batur Selatan di Kecamatan Kintamani secara positif dan signifikan yang ditunjukkan dengan hasil t-hitung 3,817 dengan nilai signifikansi 0,001. Artinya, jika lingkungan kerja mendukung petani melakukan pekerjaan, maka kinerja petani akan meningkat.

Kompetensi dan lingkungan kerja memberikan pengaruh simultan secara bersama-sama terhadap kinerja usaha tani pada Banjar Dinas Taksu Desa Batur Selatan di Kecamatan Kintamani yang ditunjukan dengan $\mathrm{F}$ hitung 38,745, dan probabilitas 0,000 . Artinya, kompetensi dan lingkungan kerja dalam sebuah usaha sangat diperlukan, dimana semakin luas wawasan dan keterampilan seseorang maka semakin berpengaruh terhadap usahanya.

Saran bagi pihak petani jeruk Banjar Dinas Taksu, memberikan gambaran tentang pentingnya kompetensi dan lingkungan kerja bagi petani Banjar Dinas Taksu Desa Batur Selatan di Kecamatan Kintamani untuk dapat meningkatkan kinerja usaha tani jeruk dengan memperhatikan kemampuan dan kenyaman kerja dari masing- masing petani.

Bagi peneliti berikutnya yang tertarik ingin menganalisis kembali aspek yang sejenis yaitu: kompetensi, lingkungan dan kinerja usaha tani jeruk diharapkan agar bisa mengembangkan penelitian ini agar memakai populasi yang lebih banyak sehingga hasil penelitiannya dapat lebih teruji keandalanya, disamping itu peneliti berikutnya diharapkan agar menguji variabel lain yang 
diduga kuat bisa mempengaruhi kinerja usaha tani jeruk seperti stres kerja, disiplin kerja, kepuasan kerja dan kompensasi.

\section{Daftar Pustaka}

Antoni Feri, (2006). Pengaruh Gaya Kepemimpinan Orientasi Tugas dan Orientasi Hubungan terhadap Motivasi Kerja dan Dampaknya pada Prestasi Kerja Pegawai Pengadilan Tinggi Tata Usaha Negara Surabaya, Tesis Universitas 17 Agustus Surabaya.

Efendi, Muhamad, (2017). Pengaruh Kompetensi dan Lingkungan Kerja terhadap Kinerja Karyawan. Jurnal IImiah Riset Manajemen.

Hidayah, (2012). Pengembangan Media Pembelajaran Ilmu Pengetahuan. Jurnal pendidikan.

Moeheriono, (2010), Pengukuran Kinerja Berbasis Kompetensi, Cetakan kedua, Ghalia Indonesia, Jakarta.

Musriha. (2011). Influences of Work Behavior, Work Environment and motivation in Clove Cigarette Factories in Kudus, Indonesia. Academic Research Intertnational,Vol. 1. pp.303314.

Nitisemito, Alex (1992). Manajemen Sumber Daya Manusia. Yogyakarta: BPFE UGM.

Pinem, Desi Natalia Br (2019). Pengaruh Karakteristik Petani, Kompetensi, Motivasi, Dan Produktivitas Terhadap Keberhasilan Usaha Petani Jeruk Di Kabupaten Simalungun Sumatera Utara. Skripsi. Program Studi Manajemen Fakultas Ekonomi Universitas Sanata Dharma Yogyakarta.

Purnami, N.L.E.D., Suwendra, I.W., Susila, G.P.A.J. (2014) Pengaruh Kompensasi dan Kepuasan Kerja terhadap Kinerja Karyawan pada UD Mente Bali Sejahtera.jurnal manajemen.

Rahmisyari, (2017). Pengaruh Kompetensi dan Lingkungan kerja terhadap Kinerja Pegawai, Jurnal JMBI. Vol 5.

Rivai, Veithzal \& Ahmad Fazhi Mohd. Basri (2005). Performance Appraisal: untuk Sistem yang Tepat untuk Menilai Kerja Karyawan dan Meningkatkan Daya Saing Perusahaan. Jakarta: PT Raja Grafindo Persada.

Riyanti (2003). Kewirausahaan dari Sudut Pandang Psikologi Kepribadian. Jakarta: Grasindo.

Robbins, Stephen (2007). Perilaku Organisasi, jilid 1 \& 2, Alih Bahasa: Hadyana Pujaatmaka, Index Kelompok Gramedia, Jakarta.Schultz, D., Schultz, S E. (2006). Psychology \& Work Today Ninth Edition. New Jersey: Pearson Education.Inc.

Suryadi, A. \& Rosyidi, H. (2013). Kinerja Karyawan ditinjau DARI Analisis Faktor Budaya Perusahaan. Jurnal Penelitian Psikologi, 4 (2), 166-180.

Sedarmayanti (2009). Lingkungan Kerja. Bandumg: Mandar Maju.

Soekartawi, et. (1986). IImu Usahatani dan Penelitian untuk Perkembangan Petani Kecil. Universitas Indonesia Press. Jakarta. Soekartawi. 2005. Agribisnis Teori dan Aplikasinya. PT. Raja Grafindo Persada. Jakarta. 
Schultz, D., Schultz, S E. (2006). Psychology \& Work Today Ninth Edition. New Jersey: Pearson Education.Inc

Undang-undang No. 13 Tahun 2003 Khususnya Pasal 1 Ayat 30 tentang Ketenagakerjaan.

Wayan, I Bagia. (2015). Perilaku Organisasi. Yogyakarta: Graha IImu 